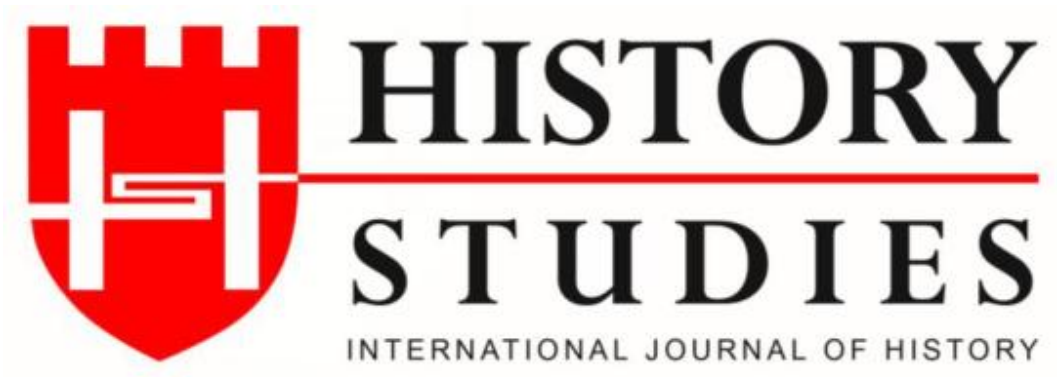

ISSN: 13094173 (Online) 1309 - 4688 (Print)

Volume 10 Issue 9, p. 231-244, December 2018

DOI Number: 10.9737/hist.2018.684

\title{
30 Ağustos Zafer ve Tayyare Bayramı Kutlamaları: Amaç, Süreç ve Kazanimlar
}

\author{
30 August Victory and Plane Day Celebrations: Objectives, Processes and Gains
}

Dr. Yücel ÖZTÜRK

(ORCID: 0000-0001-7540-7030)

Öz: Genç cumhuriyetin yönetici kadrolarl, uzun ve yoğun savaşların içerisinde yetişmişlerdir. Özellikle, I. Dünya ile Kurtuluş Savaşı sürecinde uçak ve hava kuvvetinin, savaşların sonuçlarına etkileri ile ülkelerin geleceklerinin şekillenmesindeki önemini, çok iyi kavramışlardır. Bu zihni oluşum neticesinde Türk Havacılı̆̆ını ve uçak sanayisini geliştirmeyi, yönetim hedeflerinin en başına koymuşlardır. Ülkenin kisıtlı imkânlarının, vatandașın elinde bulunan kaynaklar sayesinde aşılabileceği fikri ile Tayyare Cemiyetini kurma yoluna gitmişler ve hayata geçirmişlerdir. Türk Tayyare Cemiyeti, halkın bilinçlendirilmesi ve havacılık sanayine katkıda bulunması için her türlü yönteme başvurmuştur. Başlangıçta uçakları satın alma, akabinde kendi uçağını yapma düsturu ile ilk yıllarda oldukça önemli mesafeler kat etmiştir. Cemiyet, nizamnamesi ile 30 Ağustos gününü, Zafer ve Tayyare Bayramı olarak ilan edip, yönetim ve halkın nazarında kabul görmesini sağlamıștır. Düzenlenen etkinlikler ile beklenenin üzerinde halkın ilgisi çekilmiş, büyük miktarlarda kaynak ve destek temini sağlanmıştır. Bu destekler ile Türk Hava Kuvveti'ne birçok uçak kazandırllmıştır. Havacılı̆̆ın gelişsiminde büyük ilerleme sağlanmıştır. Ancak 1940’lı yıllardan itibaren bu uğurdaki yoğun çabalar, süreklilik ve hassasiyetini kaybetmiştir. Sonuç olarak istenen neticeye ulaşılamamış ve Türk Havacılık Sanayisi, gelişmiş devletler seviyesine çıkartılamamıştır.

Bu çallşmada, Türk Tayyare Cemiyeti'nin kuruluşundan itibaren halkı bilinçlendirmek ve destek sağlamak amacıyla yayın hayatına koyduğu Tayyare Mecmuasından faydalanılmıştır. Ülke coğrafyasının çok farklı noktalarında bulunan yerleşim birimlerinde konu ve haber yapılmış, 30 Ağustos Zafer Ve Tayyare Bayramı etkinlikleri incelenmiștir. Elde edilen kazanımlar ile kullanılan yöntemlerin, etkileri ve sonuçları, tespit edilmeye çalışılmışıtır.

Anahtar Kelimeler: Tayyare, Tayyare Bayramı, Havacılık, Türk Tayyare Cemiyeti, 30 Ağustos.

Abstract: The administrative staff of the young republic grew up in long and intensive wars. Especially, plane and Air Force, which is the most effective on war results and future of countries has a big role during World War I and the Turkish Indepence War. It has a big aim to improve industry of plane and Turkish aeronautics at the end of this mental formation. It made decision to establish the Society of Airplane with a idea which has limited opportunities of country and citizens who have sources. The Society of Turkish Airplane implements every possibility to raise the awarness of public and to develop the industry of plane. At the first years, it proceeded successfully with buying the planes in the sequel making it's own planes initially. When the society changed the 30 August day to the Victory and the Airplane Festal, it declared with the charter to the public. Additionally, this event was accepted by the registration and public. This activities attracted intense interest and it provided plenty sources and support template. The Turkish Airforce handled a lot of planes with these supportive activities. Indeed, great progress has been made in the development of aviation, but some intense efforts, lost the contiunity and precision since about 1940. Consequently, the desired level could not be reached and the Industry of Turkish Air, has not been promoted to advanced states.

This paper, since established the Society of Turkish Airplane has been benefited from Airplane Journal to provide to be aware of the public and for encouragement. 30 August Victory Day and the Airplane Festals which has different locations in the country and subject to the news examined. The results obtained and conventions used in this event has influences and consequences. Also they are determinated. 
Keywords: Plane, Plane Festal, Air Force, The Society of Turkish Airplane, 30 August.

\section{GİRIŞ}

Türk Milleti, İstiklal Harbi'nin sonucunda bağımsızlığına kavuşmuştur. Ardından Türkiye Cumhuriyeti Devleti kurulmuş ve çağdaş medeniyetler seviyesine ulaşabilmek için çeşitli faaliyetlere girişilmiştir. $\mathrm{Bu}$ faaliyet alanlarından birisi de Türk Tayyareciliğinin geliştirilmesine dönük çalışmalar olmuştur. Bu yüzden sistemsiz ve yetersiz olan ülke kaynaklarının en verimli şekilde kullanılarak yönlendirilmesi ve merkezi bir yapıda olması için 16 Şubat 1925 tarihinde Türk Tayyare Cemiyeti ${ }^{1}$ kurulmuştur. Türkiye'nin kendi uçaklarını üretebilmesi, sivil ve endüstriyel havacılığın meydana getirilebilmesi maksadıyla "Acil ve umumi bir ihtiyacın" ortaya konulması ile kurulan Cemiyet, Cumhurbaşkanı Mustafa Kemal'in himayesinde, Başvekil İsmet Paşa'nın fahri başkanlığında, Mustafa Kemal Paşa'nın eski yaverlerinden Bolu Mebusu Cevat Abbas'ın (Gürer) Kurucu Başkanlığı'nda faaliyetlerine başlamıştır. Cemiyet'in amacı havacılığın askeri, iktisadi, siyasi ve sosyal önemini tanıtmak, bu alanda ihtiyaç duyulan maddi ve manevi kaynağ 1 temin etmek olmuştur. ${ }^{2}$ Cemiyetin bu doğrultuda ki hedefleri, yakın ve uzak olmak üzere şu şekilde ifade edilmektedir: ${ }^{3}$

"1. Acil Yapılmasi gerekenler:

1. Öncelikli ve Şimdiden yapılması gerekli hususlar:

En son model de avcı tayyaresi, Keşif tayyaresi, Bombardıman tayyaresi, satın almak.

2. Tayyarelerin muhafazasina ve kullanilmasina mahsus tesisat:

Hangarlar, Benzin depoları, Tayyare/hava meydanlarl; oluşturmak.

3. Tayyarelerin kullanması için gerekli teçhizat ve mühimmatın tedarik edilmesi,

4. Tayyare tamirhanelerinin tesis edilmesi,

5.Makinist yetiştirecek okulların kurulması, -bu okulların yetiştireceği makinistler tayyarelerde iş görebilmekle beraber aynı zamanda traktör kullanmak, bir fabrikada makine idare etmek gibi işleri de yapabilirler ki böyle bir mektebin tesisi yalnı tayyarecilik noktasından değil, memleketin diğer sanayi kollarının geliştirilmesi için de son derece önemlidir.-

\section{2.İstikbalde yapılması zorunlu olanlar:}

Türk milletinin en öncelikli olarak yapması gereken bir tayyare fabrikası kurmaktır. Avcl, keşif, talim ve bombardıman tayyarelerinin bütün aksamın imal edecek ve istenilen nitelikte tayyareler meydana getirecek bir fabrika tesisi için sarf edilmesi lazım gelen paranın ehemmiyetini Türk milleti takdir edebilmektedir. Fabrika ile bir de pilot yetiştirebilecek okul tesis edilmesi kesin gerekliliktir. Türk vatanının her an ve her dakika taarruza uğrayacă̆ını düşünerekten ordunun diğer aksam ve levazımı gibi hava kuvvetinin de mümkün olduğu süratle arttırlması cemiyetin en birinci emelidir."

\footnotetext{
${ }^{1}$ Türk Tayyare Cemiyeti Nizamname-i Esasisi, Ankara Matbaas1, 1341, mukaddeme ve s. 1. , (Gürer, 2007, s. 285 286),

1935'te Cemiyet'in adı "Türk Hava Kurumu” olarak değiştirilmiş; ancak makalede bütünlük olması düşüncesi ile eski adı kullanılmıştır.

${ }^{2}$ Türk Tayyare Cemiyeti, Nizamname-i Esasisi, Ankara Matbaas1, 1925, s.11.

${ }^{3}$ Tayyare Cemiyeti Mecmuası,10 Aralık 1925, Ankara, No:16-18, s.3.

${ }^{4}$ Tayyare Cemiyeti Mecmuasi,10 Aralık 1925, Ankara, No:16-18,s.3.
} 
Tayyare Cemiyeti, kuruluş amaçları doğrultusunda, belirlediği hedeflere ulaşabilme yolunda tanıtım, öğretim ve teşvik metotlarını araç edinmiş bu araçların işlevselliği açısından da her yer ve şartta çok farklı etkinlikler düzenleme fikrini benimsemişti.

\section{1- 30 AĞUSTOS ZAFER VE TAYYARE BAYRAMI}

Tayyare Cemiyeti yöneticileri tarafindan, etkin tanıtım ve toplumu bilinçlendirme etkinliklerinin; Tayyare Bayramlarında düzenlenecek faaliyetler ile sağlanması kararlaştırılmıştı. Bu maksatla cemiyet, Millî Mücadele'yi kesin zaferle sonuçlandıran Başkomutanlık Meydan Muharebesi'nin yıl dönümünü takip eden gün olan 31 Ağustos'u, "Türk Tayyare Bayramı" olarak kabul etmişti. Cemiyet bu bağlamda nizamnamesinde, "Türk Tayyare Cemiyetinin bi'l-umûm şu'abât-ı, mahalli merasim ve eğlenceler tertip ederek cem-î iânat nizamnâmesine tevfîken sûr-î muhtelife ile cem-î teberrû'âta gayret ederler" ifadeleri ile tüm yurda ve halka duyurdu. ${ }^{5}$

Havacılığın gelişiminin temel unsuru savaş uçakları idi. Topluma anlatma ve tanıtma zamanlarının tarihsel zaferlerin yıldönümü kutlamalarına denk getirilmesi son derece anlamlıydı. Daha sonraki düzenlemeler ile Tayyare Bayramı'nın Türk ordusunun kara, deniz ve hava kuvvetlerince kutlanan "Zafer Bayramı"6 törenleriyle aynı gün yapılmasına karar verildi. Zafer Bayramlarında düzenlenecek tören ve etkinlikler hakkında İcra Vekilleri Heyeti'nin, 25 Ağustos 1926 tarihli kararnamesi ile 30 Ağustos'un Tayyare Cemiyeti'nin de özel günü olduğu için kutlamalarda Cemiyet ile birlikte hareket edilmesinin gerekliliği bildirilmişti. $^{7} 30$ Ağustos tarihinin yıllar boyunca, 27 Mayıs 1935 tarihli Ulusal Bayram ve Genel Tatiller Hakkında Kanun, "Tayyare Bayramı” ifadesine yer vermemiş ve 30 Ağustos'u sadece "Zafer Bayramı" olarak tanımlamışt. ${ }^{8}$ Halk nazarında ve basında "Zafer ve Tayyare Bayramı" olarak ifade bulmasinın ana sebebi buydu.

1935'te yer verilen bu düzenleme sonrasında 30 Ağustos Tarihi, uzun süre zihinlerde

Tayyare Bayramı olarak yerini korumuştu. Ancak 1940'lı y1llardan itibaren gerekli hassasiyetin sürdürülmemesi neticesinde uygulamalarda olduğu gibi zihinlerden de silinmişti.

\section{2- ZAFER VE TAYYARE BAYRAMI ETKINLİKLERININ YÖNTEM VE KAZANIMLARI}

Erken Cumhuriyet döneminde havacılığın hızlı gelişimini temin edebilmek ve halkın desteklerini artırabilmek maksadı ile çeşitli uygulamalara gidilmişti. Bunların başında yurdun geneline yayılan Tayyare Bayramı etkinlikleri ve bunların ifa şekilleri gelmekteydi. Örneğin, Cemiyet'e en çok maddi yardım yapan şehir, kasaba, köy, aile, kişi ya da kurumlara ait isimler, merkez idare heyetinin almış olduğu kararla satın alınan uçaklara verilmekteydi. ${ }^{9}$ Alınan kararlar doğrultusunda Cemiyet'in, Zafer ve Tayyare Bayramlarında düzenlediği en önemli etkinliklerden biri "uçaklara isim verme törenleri" olmuştu. Cemiyet icra edilen tören etkinliklerinde bu hususu, bağışı yapan şehir/kasaba halkını, satın alınan uçağın hareket edeceği meydana davet ederek uçağın gösteri uçuşundan sonra resmi görevlilerce, halkın

\footnotetext{
${ }^{5}$ Türk Tayyare Cemiyeti, Nizamname-i Esasisi, Ankara Matbaası, 1925,s.11.; (1925’te yayınlanan nizamnamenin 35. Maddesine göre "Türk Tayyare Bayramı", "31 Ağustos" olarak kabul edilmişti. Ancak ertesi sene bu "30 Ağustos" olarak değiştirilip "Zafer Bayramı” ile birleştirildi.).

${ }^{6} 1$ Nisan 1926'da Türkiye Büyük Millet Meclisi (TBMM), Başkumandan Muharebesi'nin yıl dönümü olan 30 Ağustos'u, ordu ve donanmanın “Zafer Bayramı” olarak kabul etmişti. TBMM Zabıt Ceridesi, Devre: 2, Cilt: 24, s. 7-8.

${ }^{7}$ Cumhurbaşkanlığı Arşivi: Kutu No: 1/89 (23-1), Fihrist No: 61/4.

${ }^{8}$ Düstur, Cilt: 16, Üçüncü Tertip, s. 1171.

${ }^{9}$ Türk Tayyare Cemiyeti: Esas Nizamname ve Madalya Nizamnamesi, Ankara: Hâkimiyeti Milliye Matbaası, 1932, s. 11-12
} 
huzurunda uçağa isminin verilmesi şeklinde gerçekleştiriyordu. Böylece halk, "isim koyma törenleri" ile Cemiyet'e yaptığı bağışın sonucunu izlemiş, katkıları ile satın alınan uçağın gövdesinde memleketlerinin ismini görerek bu gururu yaşamış oluyordu. Bağış yapan şehir/kasabanın ismi, uçağın gövde veya dikey şekilde kuyruğuna yazılıyordu. Böylesi bir tören hem kampanyalara ilgiyi artırmış hem de toplanan bağışın boşa gitmediğini göstermiş oluyordu. ${ }^{10}$

Cemiyet, on bin lira tutarında bağış yapan her şehir, kasaba, köy ya da kişinin, kendi isimlerini taşıyan uçağı görebileceklerini duyurmuştu. Aslında Cemiyet'in yapmaya çalıştığı son dönem Osmanlı'dan beri süregelen bağış geleneğini resmi bir karara bağlayarak halkın havacılığa katkısını teşvik etmekti. Bu girişime ilk yanıt Adana'nın Ceyhan kasabasından geldi. On bin lira tutarında bağış yaptığını duyuran kasaba halkı, Cemiyet'in satın alacağı ilk uçağa "Ceyhan" adının verilmesini istiyordu. İtalyan Ansaldo fabrikasının ürettiği, Ceyhan isimli uçağın ilk deneme uçuşu 17 Haziran 1925'te Ankara'nın At Koşusu mahallindeki kalabalık bir davetli kitlesi önünde yapıldı. 20 Haziran'da uçak, Cemiyet'in Fen Şubesi'ni organize etmekle sorumlu, dönemin meşhur havacılarından ${ }^{11}$ Vecihi Hürkuş ${ }^{12}$ tarafından Ceyhan halkına teşekkür etmek ve isimleri yazılı uçağı göstermek amacıyla Ceyhan Kasabası'na doğru yolculuğa çıkarıldı. Vecihi Bey, seyahat boyunca yerleşim birimlerine, Cemiyet'in propaganda kâğıtlarını dağıttı. Ceyhan dönüşü ise Adana semalarında helezonlar çizerek bir "gösteri uçuşu" yaptı ve burada halkın yoğun tezahüratıyla karşılandı. Cumhuriyet Halk Partisi (CHP)'nin Bölge Müfettişi Dr. Fazıl Berki Bey, Cemiyet adına bir konuşma yaptı. Buna göre; ülke savunmasında millî havacılığın ne kadar önemli bir yere sahip olduğunu, uçağın etrafını saran kalabalığa anlatmaya çalıştı. Bu gösteri ve konuşmanın ardından Cemiyet'in Adana şubesi, para bağışı için kuyruğa giren vatandaşlarla doldu. Yarım günde Adana şubesine yapılan toplam bağış, 220 bin lirayı geçmişti. ${ }^{13}$

1929 y1lı Zafer ve Tayyare Bayramı'nda, İstanbul Yeşilköy'de yapılan törende CHP Müfettişi ve Cemiyet'in İstanbul Şubesi Reisi, Kolordu Komutanı ve İstanbul Mebusları hazır bulundu. ${ }^{14}$ Yapılan yardımlar neticesinde alınmış olan uçaklar, "isim verme törenleri" sonrasında orduya hediye edildi. 1931 yılında ise yapılan yardımlarla alınmış olan 37 bağış uçağından, 6 âdetine -alan kasabalar olmaları sebebi ile- ortaya konulan etkinlikler neticesinde ve yerel halkın huzurunda "Akșehir", "İskilip", "Bayburt", "Siverek", "Bodrum" ve "Cizre" isimleri verilmişti. ${ }^{15}$

Zafer ve Tayyare Bayramlarında yapılan konuşmalarda, ülkeye yapılacak muhtemel bir uçak taarruzuna karşı alınabilecek en iyi karşı tedbirin yine uçak filosu ile karşılık vermek olacağı fikri ön plana çıkarılmaktaydı. Böylece halkın havacılığa verdiği desteğin artırılması için kamuoyu oluşturmaya yönelik çalışmalar başladı. ${ }^{16}$

\footnotetext{
${ }^{10}$ Hava Kuvvetleri Komutanlığ , Tarihçe Şube Müdürlüğü, Gönüllerden Göklere, Ankara, 2005, s. 315

${ }^{11}$ Vecihi Hürkuş, 1895 tarihinde İstanbul'da doğdu. İlkokulu Bebek'te okudu, Üsküdar'da Füyuzat-1 Osmaniye Rüştiye'sinde ve Üsküdar Paşa kapısı İdadi'sinde okudu, sanata olan ilgisinden Tophane Sanat Okulu'na geçti ve bu okulu bitirdi. Yeşilköy'deki Tayyare Mektebi'ne girerek tayyareci adayı olan Vecihi Hürkuş, 15 Kasım 1916'da tayyarecilik eğitimini bitirerek pilot diplomasını aldı ve ilk uçuşunu 21 Mayıs 1916 tarihinde yaptı. Kurtuluş Savaşı'nda ganimet olarak Yunanlardan ele geçen çeşitli uçak motorlarından istifade ederek, ilk uçağı "Vecihi K VI"'yı imal etti. İmal ettiği uçağı ile 28 Ocak 1925 tarihinde ilk uçuşunu izinsiz olarak yaptığı için cezalandırılınca istifa ederek hava kuvvetlerinden ayrıldı. Ankara'da kurulmakta olan Türk Tayyare Cemiyeti'ne katıldı. Türk Tayyare Cemiyeti'nde Fen şubesinin organizasyonun da görev aldı. (Vecihi Hürkuş, Havada, İstanbul, 2008, s. 4).

${ }^{12}$ Vecihi Hürkuş, Bir Tayyarecinin Anıları: Yaşantı, İstanbul, YKY, 2000, s. 266-281

${ }^{13}$ V. Hürkuş, Bir Tayyarecinin Anıları, s.178-189.

${ }^{14}$ Cumhuriyet, 31 Ağustos 1929, s. 1 ve 3.

${ }_{15}$ Gaziantep, 31 Ağustos 1931, s. 2; Hâkimiyeti Milliye, 1 Eylül 1931, s. 5.

${ }^{16}$ Bingöl, 1937, s. 18.
} 
Başvekil İsmet Paşa, 27 Kasım 1932'de, Tayyare Cemiyeti'nin V. Kongresi'nde, bundan sonra meydana gelebilecek bir savaşın kesin neticesini ancak uçakların tayin edebileceğini, hava saldırılarına karşı tedbir için Avrupa'nın belli başlı şehirlerinde tatbikatlar yapıldığını ifade etmişti. Bu doğrultuda İsmet İnönü, Türkiye'ye yönelik olabilecek hava saldırılarına karş1 Türk Halkının gerekli bilgi ve teçhizat ile donatılmasını istiyordu. ${ }^{17}$ Zafer ve Tayyare Bayramlarında bu konu sürekli canlı tutulmaya ve halkın bu konuda bilinçlendirilmesine gayret sarf edilmeye başlanmıştı. Bayram ve etkinlikler bu boyutlu bilinçlendirmeler açısından son derece fayda sağlamıştı. ${ }^{18}$ Belirlenen hedefler doğrultusunda Türk basın organlarının bazılarında Tayyare Bayramlarında vatandaşlara yapılan duyuru ve çağrılardan bazıları şu şekilde idi: "Aziz Yurttaş! 30 Ağustos Zafer ve Tayyare Bayramı yaklaşlyor. Bu büyük günde Türk Tayyare Cemiyeti'ne yardım etmek en büyük yurt borcudur." 19 "Vatandaş; Bugün Tayyare Bayramıdır. Unutma!", "Hava tehlikesini bilenlerin arasina katılmayanlar! Acele ediniz. Yurt, sizi ödeve çağırıyor", ${ }^{21}$ "Tayyare En Güçlü Silahtır!", 22 "Tayyare Güçlü Bekçidir!", "Uçağ olmayan bir yurt, damı olmayan bir eve benzer". ${ }^{24}$

Artık bir savaşın kaderini hava gücü tayin edeceği bilindiğine göre bağımsızlığını korumak isteyen her devlet, uçak sanayini kurmak zorundaydı. Türkiye, bu tarihe kadar Kayseri Uçak Fabrikası ile Eskişehir Uçak Tamir Fabrikası'nı kurmuştu. ${ }^{25} 1935$ 'te Ankara'daki Zafer ve Tayyare Bayramı'nda uçakların akrobasi hareketlerinin ardından törenin geçit resmi, Kayseri fabrikasında gerçekleşmiş ve planörlerin geçişi ile tamamlanmıştı. Bayram dolayısıyla Cemiyet adına söz alan Dr. Ragıp Bey, bir devletin elindeki uçak sayısının, o devletin gücünün bir göstergesi olduğunu dile getirmiş̧; dünyanın, "bu yeni silaha verdiği önemi düşünerek”, Cemiyet'e yapılmakta olan bağışların arttırılmasının, bir vatan borcu olduğunu ifade ederek sözlerini bitirmişti. ${ }^{26}$ Çünkü Türkiye'nin hava savunma sanayisi için gerekli 20-30 milyon liray1, salt devlet bütçesinden karşllayabilecek gücü yoktu. Cemiyet'in ise tedarik edebildiği rakam, bunun onda biri kadar bile değildi. $\mathrm{O}$ halde yapılmas gereken, ülkenin maruz kaldığı hava tehlikesini ve havacılığın önemini vatandaşlara anlatarak, Tayyare Bayramlarında halkı bağış yapmaya teşvik etmek idi. Bu faaliyet ve kampanyaları yürütmek, başta cemiyet olmak üzere herkesin öncelikli vazifelerinden biri olmalıydı. İsmet İnönü, 25 Mayıs 1935 'te toplanan Basın Kurultayı'nda önem ve aciliyeti bu sözlerle ifade etmişti. ${ }^{27} \mathrm{Bu}$ konuşma doğrultusunda, 25 Mayıs 1935'te Cemiyet'in tüzüğünde bazı değişiklikler yapılmıştı. "Hava Şehitlerini Anma Günü", 15 Mayıs olarak değiştirilmişti. ${ }^{28}$ Ayrıca bir de "Hava Haftası" kutlamalarının yapılması kararlaştırılmıştı. Bu hafta boyunca "konferans", "gösteri", "şenlik" gibi etkinlikler yapılarak Tayyare Bayramlarında elde edilen desteklerin artırilması hedeflendi. ${ }^{29}$

\footnotetext{
${ }^{17}$ Türk Tayyare Cemiyeti Beşinci Kongre Zabıtları 27-28 Teşrinisani 1932, Ankara: Hâkimiyeti Milliye Matbaası, 1932, s. 3-10.

${ }^{18}$ Şakir Hazım Gökmen, “Ulusal Hava Seferberliği”, Ulus, 1 Eylül 1935, s. 2.

19 Anadolu, 29 Ağustos 1934, s. 1

${ }^{20}$ Anadolu, 30 Ağustos 1934, s. 1

${ }^{21}$ Ulus, 30 Ağustos 1937, s. 2 ve 3

${ }^{22}$ Babalık, 28 Ağustos 1936, s. 1

${ }^{23}$ Babalık, 21 Ağustos 1936, s. 2

${ }^{24}$ Akşam, 30 Ağustos 1936, s. 4

${ }^{25}$ Mehmet Evsile, Atatürk Devri Harp Sanayi (1920-1938) Hasan Celal Güzel vd. (Ed.), Yeni Türkiye Yayınları, Türkler, Cilt: 17, s. 720, Ankara.

${ }^{26}$ Ulus, 31 Ağustos 1935, s. 1

${ }^{27}$ Ayın Tarihi, Sayı: 18, 1-31 Mayıs 1935, s. 103-104.

${ }^{28}$ Kurun, 17 Nisan 1936, s. 7.

${ }^{29}$ Ayın Tarihi, Sayı: 18, 1-31 Mayıs 1935, s. 136.
} 
Tayyare Bayramı ve Tayyare Şehitlerini Anma Günü'nden sonra Cemiyet her y1l 30 Ağustos ile 5 Eylül günleri arasını Hava Haftası olarak belirledi. Hafta boyunca halkı eğlendirmek suretiyle, Cemiyet'e gelir temin edilmeye çalışıldı. Bu amaçla sünnet dügünleri, balolar, fasıllar, sinema filmleri, tiyatro oyunları ve spor yarışmaları düzenlendi. ${ }^{30}$

\section{3- 30 AĞUSTOS ZAFER VE TAYYARE BAYRAMI KUTLAMA VE ETKİNLİKLERİ}

Erken Cumhuriyet dönemi yöneticileri ve kurumları, Türk Havacılığının gelişimi için hiçbir gayretten kaçınmama fikrinde idi. Bu fikri maksadın en somut ifadelerinden biri, Tayyare bayramı etkinlikleri oldu. Türk havacılığının gelişimine katkı sağlamak üzere Zafer ve Tayyare Bayramı etkinliklerinin ülke genelinde nasıl ortaya konulduğu, Türk Hava Mecmuasına yansıdığı şekli ile aşağıdaki gibi olmuştu:

\section{3-1-ILLERDE 30 AĞUSTOS ZAFER VE TAYYARE BAYRAMI KUTLAMA İLE ETKINLIKLERI}

\section{a- İstanbul'da 30 Ağustos Zafer ve Tayyare Bayramı}

30 Ağustos Tayyare Bayramı, İstanbul'da muazzam addedilmiş ve çok parlak bir şekilde kutlanmıştı. 30 Ağustos Zafer Günü ile Tayyare Bayramı'nın aynı gün icra edilmesi günü daha anlamlı bir hale getirdiğinden de bahsedildi. Dolayısıyla günün öneminin daha kutlu bir biçim aldığı ifade edilmek amaçlanmıştı. İstanbul'un binlerce esnafı bu günde tüm gelirini Tayyare Cemiyeti'ne bırakmıştı. Bu gelir İstanbul ölçeği düşünüldüğünde oldukça kıymetli bir yekûn teşkil etmişti. Bütün mağazaların, dükkânların camekânlarında "Bugünkü kazancımız Türk Tayyare Cemiyetine aittir" ibareli levhalar asılmıştı. Özellikle şoförlerin temin ettikleri ve bağışladıkları hasılatın toplamı oldukça önemli bir seviyeye ulaştı. Vapurlar, tramvaylar ve bütün seyir ve sefer vasıtaları biletlerine "onar, yirmişer ve kırkar para" zam yapmış ve bu miktarlar bağışa dönüşmüştü. Satılan rozetler de iyi bir gelire zemin hazırlamıştı. ${ }^{31}$

Tayyare cemiyeti bu güne ait kutlama etkinlikleri doğrultusunda, İstanbul'un muhtelif mahallelerinde genel nitelikli ve tüm halka açık gösteriler tertipledi. Sarayburnu gazinosunda yapılan gösteri, son derece keyif verici ve mükemmel bir hazırlık eseri olarak sahnelenmişti. Gazi Paşa Hazretleri' nin heykeli önünde Riyaset-i Cumhur/Cumhurbaşkanlığı orkestrası ekibi, konser vermişti. Gösteriye yoğun bir katılım olmuş ve bağışa dönüşecek gelir istenen seviyenin üzerinde olmuştu. Tayyare balosu, çok zevkli vakitlere sahne olmuş, iyi dans edebilenler arasında "Çarliston Müsabakası" dahi yapılmıştı. ${ }^{32}$ Üsküdar'da Taksim bahçesinde, Büyükdere, Sarıyer ve Kadıköy'de gösteriler yapılmış ve havai fişekler eşliğinde eğlencelere gece boyunca devam edilmişti. ${ }^{33}$

İstanbul'da yapılan bu etkinliklerin, her bölgeye yayılmasına azami dikkat gösterilmiş ve çok büyük bağışların toplanabilmesi hedeflenmişti. Ayrıca yapılan etkinliklerle toplumun sosyal hayat değişimine katkı sunulması düşünülmüştü. Cemiyetin ana amacı olan etkinliklere yoğun katılımın ve bağışların üst seviyede gerçekleşebilmesi temin edilmişti. Bunun için

\footnotetext{
${ }^{30}$ Sabah, 26 Ağustos 1938, s. 1; Sabah, 27 Ağustos 1938, s. 2.

${ }^{31}$ Türk Hava Mecmuası, Sayı: 33, 1927, s.284.

${ }^{32}$ Çarliston, 1920'lerde son derece yaygın olan bir caz dansı türüdür. Tek başına, çiftlerle ya da grup halinde yapılır. Temel ayak figürü, ayakuçlarının içe, topukların dışa döndürülerek atılmasından oluşur. ABD'nin bütün güney eyaletlerinde bilinen, özellikle de Güney Carolina'da bulunan, Charleston şehri ile özdeşleştirilen, AfroAmerikalılar'a özgü bir halk dansıdır. Türkiye'de 1925 yılından itibaren ortaya çıkmıştır. (www.ezgikonucu.com)

${ }^{33}$ Türk Hava Mecmuası, Sayı: 33, 1927, s.284.
} 
Şehrin tüm halk ve esnafının katılımı temin edilebilmişti. Yine gelirin artırılabilmesi için etkinliklerde rozet satışı, ulaşım vasıta ücretlerinin artım bedelinin bağışa dönüştürülmesi gibi yollara da başvurulmuştu. Katılımların yoğun ve çeşitli kesimlerden olması cemiyetin amaçlarına doğrudan katkı sağlamıştı.

\section{b-Ankara'da 30 Ağustos Zafer ve Tayyare Bayramı}

Düşmanı yurttan kovuşun ve büyük esaret ile zilletten kurtularak bağımsızlığın elde edildiği 30 Ağustos tarihinin yıl dönümü; başkent ve hükümet merkezi olan Ankara'da kapsamlı ve neşeli bir şekilde kutlanmıştı. 30 Ağustos Zafer ve Tayyare gününü diğer bir ifade ile her iki bayramı birleştiren bugün için günler öncesinden hazırlıklar başlatılmıştı. 29 Ağustos'ta bayramın müjdecileri olarak bir kısım tayyare, Ankara'ya gelmişti. Sabahtan itibaren Ankara'da her yer süslenmiş, caddeler, sokaklar, al bayraklarla donatılmış, şehir bir nevi gelincik tarlasına benzetilmişti. ${ }^{34}$

Hazırlanmış program gereği, erkânı mülkiye ve askeriye ve Ankara'da bulunan bütün ecnebi sefaretler; en büyük kumanda makamına vekâlet eden ve orduyu saygın ve kabul gören şahsiyetinde temsil eden Erkânı Harbiye Umumiye Reisi Fevzi Paşa Hazretleri’ni ziyaret ve tebrik etmişlerdi. Törenin ziyaret ve tebrikler kısmı sona ermiş ve Sarı Kışla meydanında bir geçit töreni yapılmıştı. Türk Ordusu'nun mensupları, çok heybetli bir görüntü sergilemişti. Geçit töreni esnasında Gazi Mustafa Kemal Paşa Okulu ve civarında, kırk kadar tayyare, filolar halinde uçmuş, şehrin her tarafına tayyare cemiyetinin şükranlarını, minnetlerini, selamlarını içeren beyannameleri ve tayyare rozetlerini havadan atmak suretiyle dağıtmışlardı. ${ }^{35}$

Milletin gayretinden, fedakârlığından, azminden doğan ve kısa bir sürede büyük bir teşkilat seviyesine erişen Tayyare Cemiyeti'nin resmikabulleri gerçekleştirildi. Resmikabule Büyük Millet Meclisi Reisi, Başvekil ve Erkan-1 Harbiye Umumiye Reisi Paşalar, Erkan-1 Mülkiye ve Askeriye ve Mebuslar; katılmışlardı. Resmikabulün sonrasında Ankara'ya gelen Misır el-ittihat heyeti, Spor Cemiyeti Reis'i Fuat Beyi ziyaret ve tebrik etmişti. Bu heyete de günün anlam ve önemi doğrultusunda hatıra olmak üzere birer tane tayyare rozeti hediye edilmişti. Törene katılan Ankara'nın önde gelen kişilerinden cemiyete önemli miktarlarda bağış yapılmış ve bağışta bulunanlar altın madalyalarla ödüllendirilmişlerdi. ${ }^{36}$

Tayyare cemiyeti tarafından tayyareye ve tayyareciliğe karşı gösterilen ilgiyi artırmak üzere, tayyare meydanında biri büyük diğeri küçük iki yolcu tayyaresiyle halk, ücretsiz olarak Ankara üzerinde gezdirilmişti. Ankara'yı aylı yıldızlı tayyareler kaplamıştı. Halkın tayyare ile uçmak için gösterdiği istek ve arzu, Türk tayyareciliği geleceğinin ümitle dolu olduğunu göstermekte idi. Uçuşlar, guruba kadar sürmüş ve şehir elektriklerle aydınlanmaya başlayıncaya kadar devam etmişti. ${ }^{37}$

Tayyare cemiyeti tarafindan tertip ve tanzim edilen yeni bahçe ile serbest balo için ayrılan bahçenin gazinosu; fenerler, fişek eğlenceleri, saz, caz ve müzik sesleri ile coşkun bir eğlence ortamı halini almıştı. Çok yoğun ilgi ve kalabalık oluşmuştu. Zaman aralıkları ile dolaşan fener alayları bütün eğlencelere daha başka bir mana ve güzellik katmıştı. ${ }^{38}$

\footnotetext{
${ }^{34}$ Türk Hava Mecmuası, Sayı: 8, 15 Eylül 1926, s. 12-13.

${ }^{35}$ Türk Hava Mecmuası, Sayı: 8, 15 Eylül 1926, s. 12-13.

${ }^{36}$ Türk Hava Mecmuas1, Sayı: 8, 15 Eylül 1926, s. 12-13.

${ }^{37}$ Türk Hava Mecmuası, Sayı: 8, 15 Eylül 1926, s. 12-13.

${ }^{38}$ Türk Hava Mecmuası, Sayı: 8, 15 Eylül 1926, s. 12-13.
} 
Sonuçta 30 Ağustos Zafer ve Tayyare Bayramını bütün halk, bugünleri kendisine verenlere, yaşatanlara, yaratanlara minnet ve şükranla dolu olduğu halde coşkun bir heyecan içerisinde yorulmadan, usanmadan sabaha kadar kutlamıştı. ${ }^{39}$

Ankara'da gerçekleştirilen törenlerin daha görkemli ve Tayyare Cemiyetinin de çok daha önemli bir yere konularak şekillendirildiği görülmekteydi. Tayyare Cemiyetinin ülkenin diğer yerlerinde yapılan törenlerdeki üretkenliğinin başkentte daha ziyadesi ile hissedilmesinin önemli göstergelerinden birisi tayyarelerin burada yaptıkları gösteri uçuşları idi. Memleketin her köşesinde son derece görkemli ve Tayyare Cemiyeti hedefleri doğrultusunda düzenlenen etkinliklerin tamamı Ankara'da da aynı ile icraya konulmuştu. Tayyarelerin bir kısmı tören öncesi Ankara'ya getirilmiş ve bu törenler esnasında halkın, tayyarelere bindirilmek suretiyle uçuş yapmaları sağlanmıştı. Bu uçuşlar halk ile cemiyetin ve hedeflerin kesişmesinin mükemmel birer örneğini teşkil etmişti. Çünkü halk bu uçakların kendi yardım ve fedakârlıkları ile alınmasının haklı gururunu yaşarken, birde kendi eserlerine erişip, kullanmış olmanın mutluluğunu hissedebiliyordu. Ayrıca başta Gazi Mustafa Kemal Paşa olmak üzere Ankara'da bulunan tüm yönetici ve önde gelen kişilerin bu yolda birlik içerisinde hareket etmiş olmaları da halka bu yolda olmalarının isabetini göstermiş oluyordu.

\section{c-İzmir'de 30 Ağustos Zafer ve Tayyare Bayramı}

30 Ağustos Zafer ve Tayyare Bayramı, İzmir'de büyük bir heyecanla kutlanmıştı. Şehir baştanbaşa büyük bir ihtimamla süslenmişti. Saat on bir de kışla meydanında Askeri birlikler toplanmıştı. Mevki-i Müstahkem Kumandanı Fuat Paşa, Askeri birlikleri selamladıktan sonra bir konuşma yapmıştı. Fuat Paşanın konuşmalarının ardından Teğmen Celal Bey'in günün anlam ve önemini içeren konuşmaları yer almıştı. Konuşmaların ardından İzmir'in hamiyetli celep esnafına, tayyare cemiyetine yaptıkları bağışların şükran göstergesi olmak üzere değerli taşlarla süslü madalyaların takdim töreni yapılmış bu münasebetle Vali Kazım Dirik Paşa tarafından da bir konuşma yapıılmıştı. ${ }^{40}$

Yapılan etkinlik ve törenlerde Cemiyete ve Türk Havacılı̆̆ına destek verenler asla unutulmamış ve hep ön planda olmaları sağlanmıştı. Yaptıkları bağış ve destekler hiçbir vakit karşılıksız bırakılmamış aksine en güzide ödüller ile taltif edilmişlerdi. Bu törende de görüldüğü üzere Türk Havacılığının gelişim sürecine katkı sağlamış olanlar her zaman cemiyet tarafından şükranla beslenmişlerdi.

\section{d-Urfa'da 30 Ağustos Zafer ve Tayyare Bayramı}

30 Ağustos Tayyare Bayramı, Urfa'da da takdire şayan bir şekilde icra edilmişti. Tayyare Cemiyeti Şubesi'nin düzenlediği çeşitli eğlence, sinema, gösteri, piyango ve radyo takipçileri ile birlikte bayram etkinliklerine yoğun bir katılım gerçekleşmiş ve cemiyete önemli bir miktarda bağış temin edilmişti. Sabah başlayan kutlamalarda, Süvari Fırkası Müfettiş Bahri Bey tarafından Tayyare Bayramı'nın anlam ve önemini belirten bir konuşma yapılmıştı. ${ }^{41}$

Cemiyet, Urfa'da Tayyare Bayramına yoğun katılım sağlamak için radyo programları düzenledi. Böylelikle günün en etkili iletişim aracı olan "radyo" devreye sokulmuş ve takipçi olan halkın katılımı gerçekleştirilmişti. Urfa'da ki bu bayram kutlamaları, bir kez daha Cemiyetin Türk Havacılığını istenen seviyeye getirebilmek için her yola başvurmaktan geri kalmadığını göstermişti. Cemiyet kuruluş amaçları doğrultusunda havacılığa katkı ve destek

\footnotetext{
${ }^{39}$ Türk Hava Mecmuası, Sayı: 8, 15 Eylül 1926, s. 12-13.

${ }^{40}$ Türk Hava Mecmuası, Say1: 9, 1 Ekim 1926, s. 2.

${ }^{41}$ Türk Hava Mecmuası, Say1: 33, 1927, s.284.
} 
sağlamak için her türlü yolu denemek ve kullanmak fikrini her sahada ortaya koymaktan hiçbir vakit imtina etmemişti.

\section{e-Kütahya'da 30 Ağustos Zafer ve Tayyare Bayramı}

Kütahya'da 30 Ağustos Tayyare Bayramı, çok iyi bir hazırlık ile kutlandı. Sabah vakitlerinden itibaren tüm halk ve memurlar askeri binanın önünde topland. Askerlik Şube Başkanı/Reisi; Hayri Bey; Tayyare ve Zafer Bayramı şerefine günün anlam ve önemini belirten bir konuşma yaptı. Hayri Bey'in ardından Tayyare Şubesi Reisi Ali Bey, tayyarenin, gelecekteki savaşlarda "en gelişkin ve yeterli silah konulu” öğretici bir konuşma yaptı. Konuşmaların ardından Asker Alma binasından, Tayyare Şubesi'ne geçilerek tebrik töreni yapıldı. Gece ise belediye parkında yapılan gösteriler sonunda 230 lira Tayyare Cemiyeti hesabına gelir olarak toplandı. ${ }^{42}$ Yapılan bu kutlama etkinliklerinde de görüldüğü üzere, ilk amaç toplumun havacılık konusunda bilgilenmesini sağlamaktı. Bu doğrultuda eğitici konuşmalara yer verilmekteydi. Ardından vatandaşı teşvik edici hareket ve konuşmalar yer almaktaydı. Tüm bu etkinlikler sonrasında ise esas amaca hizmet eden yardımlar toplanmakta ve havacılığın gelişimi için yeterli kaynak oluşturulmaya özen gösteriliyordu.

\section{f-Zonguldak'ta 30 Ağustos Zafer ve Tayyare Bayramı}

30 Ağustos Zafer ve Tayyare Bayramı, Zonguldak'ta yoğun kalabalıkla kutlanmaya başlandı. Şehir de bulunan tüm resmi daire ve kurumlar ile özel mağaza ve dükkânlar, defne dalları ve bayraklar ile süslendi. Limanda demirli bulunan tüm gemiler ve onlara eşlik eden deniz vasıtalarının tamamı, alay sancakları ile donatıldı. Sabah saat sekiz buçukta, Valilik personeli, halk, tüm öğrenciler ve maden ocaklarının çalışanları, bayraklarla Tayyare Cemiyeti önünde toplandı. İlde görevli olan Polis ve jandarma unsurlarından birer müfreze, törene katılmak üzere hazır bulundu. Belediye Başkanı Hasan Fehmi Bey, bu büyük ve önemli gün hakkında günün anlam ve önemini içeren veciz bir konuşma yaptı. Konuşmanın ardından Askerlik Şubesi'ne hareket edilmiş ve İstiklal Marşı'nın söylenmesi ile kutlamalar başlamıştı. Burada sırası ile Şube Başkanı, tayyare ve hava gözlem istasyonu Müdürü Mülazım Muhit Bey'in, Vali Hüseyin Hasan'ın, Tayyare Cemiyeti Reisi Binbaşı Fikri Bey ve Muallime Bedia Hakkı Hanım; tarafından Tayyare ve Zafer Bayramlarına ait coşkulu konuşmalar yapılmıştı. ${ }^{43}$

Yirmi bir pare top atışı yapıldı. Limanda demirli gemiler ile fabrikalar da beş dakika boyunca düdük çalarak merasime katıldı. İl genelinde bulunan tüm lokanta, gazino, birahane, kahvehane, bakkal ve kasap gibi esnaf; o gün boyunca elde ettikleri tüm geliri, tayyare cemiyetine hibe ve armağan etti. Gece her taraf elektrikle aydınlatılmış, orta mektep binasında tayyare şerefine bir balo tertip edilmişti. ${ }^{44}$

Zonguldak’ta düzenlenen kutlamalar da benzer şekilde, öncelikle halkın bilinçlenmesi amaçlı konuşmalarla başlatılmıştı. Bu örnekte görüleceği üzere Zafer ve Tayyare Bayramlarına yoğun katılımın sağlanabilmesi, öncelikli hedefler arasındaydı. Kutlamalara, etkinliğin icra edildiği mahalde ne mevcut ise katılımına çabalanmıştı. Sokak, cadde ve binalar; yoğun şekilde süslenerek dikkat çekmeye çalışılıyordu. Yoğun katılım ve etkili konuşmalar sonunda yardımların en üst seviyede gerçekleşmesine azami gayret sarf edilmişti. Bunun sonucunda tüm işyerleri, o günkü gelirlerini cemiyete bağışlamışlardı.

${ }^{42}$ Türk Hava Mecmuası, Say1: 33, 1927, s.283.

${ }^{43}$ Türk Hava Mecmuas1, Say1: 33, 1927, s.283.

${ }^{44}$ Türk Hava Mecmuası, Say1: 33, 1927, s.283. 


\section{3-2-İLÇE VE BELDELERDE 30 AĞUSTOS ZAFER VE TAYYARE BAYRAMI KUTLAMA ILE ETKINLIKLLERI}

\section{a-Ödemiş’te 30 Ağustos Zafer ve Tayyare Bayramı}

30 Ağustos Tayyare Bayramı, Ödemiş’te ${ }^{45}$ görkemli etkinlikler ile kutlandı. İlçede bulunan tüm gazino, lokanta ve benzeri ticarethaneler kendi dükkânlarına birer mühürlü sandık koymak sureti ile günlük hasılatlarının bir kısmını Tayyare Cemiyetine bağışlayacaklarını ilan etmişlerdi. Gösterilerin büyük kısmı, Türk Ocağı Bahçesi'nde parlak bir şekilde yapıldı. Halaskar Gazi Paşa Hazretlerinin bir fotoğrafı müzayede yolu ile geliri cemiyete bırakılmak üzere 145 liraya Baro Reisi Hüseyin Ekrem Bey'e satılmıştı. Başta Kaymakam Orhan Sami, Akseki Bankası Heyeti İdare Reisi Hasan Fehmi, Baro Reisi Ekrem, Şube Reisi Abidin, Doktor Rıza, Eczacı Osman ve tüccar Sttkı Beyler olduğu halde tüm Ödemişliler etkinliklerde yer almıştı. ${ }^{46}$

Ödemişte tören, yukarıda ifade edilen amaç ve ilkeler doğrultusunda kutlanmıştı. Burada yine cemiyetin gelir temini için farklı bir metot olarak "önemli bir kişinin” fotoğrafının satışı ile gelire dönüşümü görülmektedir.

\section{b-Şile ve Ağva'da 30 Ağustos Zafer ve Tayyare Bayramı}

30 Ağustos Tayyare Bayramı etkinlikleri, Şile'de ${ }^{47}$ Ağva Nahiyesi Dispanseri olan Tabip Yahya Bey'in oğlu Namık Bey tarafından "model uçak yapımı kapsamında”, - Model uçak yapımı, Tayyare Cemiyeti'nin kuruluş yıllarında gençleri havacılığa yönlendirmek üzere teşvik ettiği bir alan idi- tasarlanıp imal edilen "istanbul tayyaresi modelinin" Tayyare Cemiyeti'ne bağış kapsamında müzayede ile 629 lira 79 kuruş bedel ile satılması sonucunda başlamıştı. Ardından Yaylalı köyü çiftçilerinden Mustafa Efendi 50, Şile Belediye Reisi Vahap Bey 100, Şile'de inşa edilen okul binasının müteahhidi İranî Hayrullah Efendi 120, Şile'de Fırıncı Ali Usta ise 150 lira bağışta bulunmuşlard. ${ }^{48}$

$\mathrm{Bu}$ etkinlikte, Tayyare Cemiyeti'nin amaçları doğrultusunda, halkın bilinçlenmesi ve havacılık insan kaynağının oluşturulabilmesi düşüncesinden hareketle ortaya konulan "model uçak yapımının” teşviki ile bağışa nasıl dönüştürüldüğü görülmüştü. Gençler, model uçak yapımına teşvik edilmek sureti ile hem bu alanda bilgi sahibi olmaları sağlanmış hem de havacılık sahasının ihtiyaç duyduğu bilinçli bir insan kaynağı oluşturulmuş idi.

\section{c-Ayaş, Haymana, Gümüşhacıköy'de 30 Ağustos Zafer ve Tayyare Bayramı}

Ayaş'ta $^{49}$ Zafer ve Tayyare Bayramı münasebetiyle Tayyare Cemiyetine bağış kapsamında bir saat müzayedeye konulmuş ve halkın yoğun heyecan ve arzusu doğrultusunda 378 lira hasılat elde edilmişti. ${ }^{50}$ Zafer ve Tayyare Bayramı kutlamaları esnasında Gümüşhacıköy ${ }^{51}$ halkı tarafından tayyare cemiyetine önemli miktarda bağış yapılmıştı. ${ }^{52}$

Haymana'da Zafer ve Tayyare Bayramı Günü olan 30 Ağustos'ta Tayyare Cemiyeti yararına tertip edilen etkinliklerde vatanperver halkın gösterdikleri hamiyet neticesinde bin lira

\footnotetext{
${ }^{45}$ Günümüzde İzmir'e bağlıdır.

${ }^{46}$ Türk Hava Mecmuası, Sayı: 33, 1927, s.285

${ }^{47}$ Günümüzde İstanbul'a bağlı, Ağva da Şile İlçesi'ne bağlı bir beldedir.

${ }^{48}$ Türk Hava Mecmuası, Say1: 33, 1927, s.285.

${ }^{49}$ Günümüzde Ayaş ve Haymana İlçeleri Ankara'ya bağlıdır.

${ }^{50}$ Türk Hava Mecmuası, Say1: 8, 15 Eylül 1926, s. 22.

${ }^{51}$ Günümüzde Amasya'ya bağlıdır.

${ }^{52}$ Türk Hava Mecmuası, Sayı: 8, 15 Eylül 1926, s. 22.
} 
hasılat temin edilmişti. ${ }^{53}$ Küçük ölçekli yerleşim birimlerinde icra edilmiş olan etkinliklerde yine cemiyetin her unsuru, Türk havacılığının gelişim yolunda kullanıldığı görülmüştür. Ayrıca ölçek ve imkânlarına bakıldığında çok küçük olsalar da cemiyet vasıtası ile Türk Havacılığına büyük destekler yapmışlardı. Bu da bize halk ve cemiyet arasında oluşturulmuş olan bağın kuvvetini ve cemiyetin bayramları nasıl aktif ve teşvik edici olarak kullanabildiğini göstermektedir.

\section{d-Kağızman'da 30 Ağustos Zafer ve Tayyare Bayramı}

Tayyare Bayramı, Kağızman'da ${ }^{54}$ halkın katılımı ile görkemli şekilde kutlanmıştı. Saat 10 'da ilçe yöneticileri, memurlar ve halk, ilk önce Askerlik Şubesi ardından Tabur Komutanlığı Makamlarını ziyaretle tebriklerini sunmuşlardı. Ardından heyet ve halk, Millet Bahçesi'ne geçmiş ve burada Tayyare Şubesi Reisi Binbaşı Alaattin Bey tarafından "Tayyareciliğin Bugünkü Vaziyeti" konulu konuşmayı dinlemişlerdi. Alaattin Bey'in konuşmasının ardından Uşak Şeker Fabrikası tarafından üretilmiş "yerli imal” kutu şeker, bir tepsi içerisinde, açık artırma usulü ile müzayede başlangıç bedeli beş liradan, geliri cemiyete kalmak üzere satışa çıkartılmıştı. Cemiyete ve Türk Havacılığına katkı sağlamak için halk arasında büyük bir çekişme meydana gelmiş ve sonunda kutu şeker, Hasan Kaleli Kıyam Bey’e 409 lira 15 kuruş bedel karşılığında satılmıştı. Bayram gününü takip eden akşamdan ertesi sabaha kadar ise fener alayları düzenlenmiş ve etkinliklere devam edilmişti. ${ }^{55}$

Kağızman Tayyare Bayram etkinlikleri cemiyetin bağışları artırmanın yanında ülkenin milli şeker fabrikalarında üretilmiş olan bir ürünü de sahneye koymuş ve milli üretimin önemi ile havacılık arsında bir köprü kurmuştu. Aynı şeker üretiminde olduğu gibi ülkenin gelecekte bir gün kendi tayyarelerini üreteceği zihinlere işlenmişti. Görüleceği üzere Tayyare Cemiyeti, bu bayramlarda ülkenin tüm varlık ve potansiyelini devreye sokarak azami fayda elde etmişti.

\section{e-Ergani’de 30 A ğustos Zafer ve Tayyare Bayramı}

Zafer Ve Tayyare Bayramı Günü olan 30 Ağustos, Ergani ${ }^{56}$ Maden İşletmeleri'nde $^{57}$ çok anlamlı bir şekilde kutlanmıştı. Eyüp Sabri Bey'in ${ }^{58}$ de katıldığı çeşitli etkinlikler yer almıştı. $\mathrm{Bu}$ kutlama ve etkinlikler neticesinde halk tarafından cemiyete önemli miktarda bağ 1 ş yapılmıştı. ${ }^{59}$

Ergani de icra edilen Zafer ve Tayyare Bayramı etkinliklerinin, her şart ve mahalde elde bulunan tüm imkânlarla yerine getirilmesine çalışıldığının ve amaçların gerçekleşmesi için her ortamın kullanıldığına güzel bir örnek teşkil etmiştir.

\footnotetext{
${ }^{53}$ Türk Hava Mecmuası, Sayı: 8, 15 Eylül 1926, s. 22.

${ }^{54}$ Günümüzde Kars'a bağlidır.

${ }^{55}$ Türk Hava Mecmuası, Sayı: 33, 1927, s.284.

${ }^{56}$ Diyarbakır'a bağlı ilçe.

57 Ergani maden bakır yatağı, Elâzığ ilinin Maden ilçesi sınırları içerisinde bulunmaktadır. Bu yatağın doğu kıyısında Hititlerden önce maden çıkarılmaya başlandığı bilinmektedir. Halen Etibank'ın işletmesi durumunda olan yataktan "glory hole" metoduyla, yani açık işletme ve yeraltı nakliyatı tarzında maden çıkartılmaktadır. Türkiye'nin en eski maden yatağıdır. (Güner Göymen-Aslaner, Doğu Anadolu'da Bulunan Ergani Maden Bakır Yatağının ve Bilhassa Yantaşlarının Maden Mikroskobik İncelenmesi, Maden Teknik Arama Enstitüsü, Ankara, s. 177).

${ }^{58}$ Eyüp Sabri Akgöl, 1876 yılında Ohri'de doğmuştur. Harp Okulu'nu bitirdikten sonra Osmanlı ordusuna katılarak, Balkanlar'da yürütülen çete savaşlarında görev aldı. Daha sonra İttihat ve Terakki Cemiyetinin ilk üyelerinden biri oldu. 1910 yılında İttihat ve Terakki merkez-i umum-i üyeliğine seçildi. Birinci Dünya Savaşı'na kadar bu partinin en üst kademe yöneticilerinden biri olarak çalıştı. Millî mücadeleye katılldı ve TBMM'de Eskişehir Milletvekilliği yaptı. Çocuk Esirgeme Kurucularından biri olan Eyüp Sabri Akgöl, 16 Ağustos 1950'de İstanbul'da vefat etti. (Millet Büyük Larousse Sözlük ve Ansiklopedi, Birinci Cilt, 1986).

${ }^{59}$ Türk Hava Mecmuası, Sayı: 8, 15 Eylül 1926, s. 22.
} 


\section{f-Mecitözü'nde 30 Ağustos Zafer ve Tayyare Bayramı}

Sabahın erken saatlerinden itibaren kaymakamlık ve askeri birim memurları ile halk, Askerlik Şubesi önünde toplandı. Bu durum kutlama etkinliklerin başladığı anlamına gelmekteydi. Şube Başkanı Binbaşı Hüseyin Hasan Bey, silahlı kuvvetler ve havacılık hakkında günün anlam ve önemini belirten etkileyici bir konuşma yaptı. Bu konuşmanın ardından İlçe Kaymakamı Abdül Vahap Bey, Türk’ün dehasını, tarihini, büyüklügünü içeren, halkı coşturan bir söylev verdi. Gece boyunca fener alayları ve geçit törenleri ile şenlikler devam etti. ${ }^{60}$

Yukarıda görüldüğ̈̈ üzere Mecitözü ${ }^{61}$ ilçesinde Zafer ve Tayyare Bayramı etkinliklerle kutlanmıştır. Öncelikle halkı bilgilendirici ve ardından toplumun havacıllı̆̆ desteklemesine yönelik teşvik edici konuşmalara yer verilmekteydi. Bu kutlamalarda eğlence tarzlı gösteri ve fener alaylarına yer verilmek suretiyle de halkın zihninde havacılığın kalıcı olarak yer etmesi hedeflenmekteydi.

\section{SONUC}

Türk Milleti, Osmanlı Devleti'nin son döneminden itibaren yoğun, sürekli ve tüm kaynakları tüketici savaşlar yaşamıştır. Tüm bu savaşlar içerisinde havacılık unsurlarının, savaşın seyrini nasıl değiştireceği bizzat yaşanarak görülmüştür. Savaşların yıkıcılı̆̆ının yanında, öğrenilen diğer bir hususta, havacılığın, sadece savaşların seyrini değiştirmekte değil, ülkelerin geleceklerinin tesisinde de son derece öneme sahip olduğu olmuştur.

Yapılması gereken Türk Havacıllğının geliştirilmesi ve ileri ülkeler seviyesine ulaştırılmasıydı. Tüm bu düşüncelerle hareket eden genç Türkiye Cumhuriyeti'nin yöneticileri, ülkenin yıpranmış tükenmeye yüz tutmuş kaynakları içerisinde bu gelişim sürecine nasıll katkı sağlayacaklarının arayışı içine girmişlerdir. Yapmalarının gerektiğinin farkında, yapabileceklerinin ise kaynaklarla mümkün olabileceğinin farkındaydılar. Ülkenin az gelişmişlik ve ekonomik yetersizlikleri doğrultusunda milletin desteğine başvurmaktan başka çarelerinin olmadığını düşünüyorlardı. Bu düşüncelerini gerçekleştirebilmek için halkın kaynak ve desteğini esas alacak, onlarla birlikte hareket edecek bir oluşuma gerek duymaları üzerine Türk Tayyare Cemiyetinin kurulmasına karar vermişlerdir. Türk Tayyare Cemiyeti, yakın ve uzak hedeflerini belirleyerek halkın desteğiyle Türk Havacılığını arzu edilen seviyeye çıkarmak görevi ile yola çıkartılmıştır. Cemiyet, istenen seviyede desteği yakalayabilmek için halkın bilinçlenmesi, havacılığın öneminin kavranması ve ülkenin bekası için vazgeçilmez bir unsur olduğunun anlaşılması amacıyla birçok faaliyete girişmişti. Bu amaçları doğrultusunda 30 Ağustos Zafer Bayramı gününün, Tayyare Bayramı olarak da kutlanılması için gerekli girişimlerde bulunulmuş ve bunda başarılı olunmuştur. Artık 30 Ağustos tarihi yurdun tüm genelinde, 30 Ağustos Zafer ve Tayyare Bayramı olarak kutlanmaktaydı. Cemiyet de bu günlerde azami gayret göstererek, yaptığı çeşitli etkinliklerle halkı cezbederek amaçları doğrultusunda yönlendirmekteydi. Bu kutlamalar esnasında mutlaka tayyareciliğin önemi, gelecekteki yeri, sanayinin gelişiminde oynayacağ 1 rolü, memleket insanının gelişimine sağlayacağ katkı, gelişmiş devletlerin bu alanda geldikleri yeri içeren konuşmalara yer verildi ve anlatımlarla, halkın ilgisinin çekilmesi yoluna gidildi, ardından yüksek düzeyde maddi yardımlar sağlandı. Yine bayram etkinliklerinde halkın sağladığı destekler bizzat ifşa edildi. Böylelikle halkın yaptığı yardımların, ne maksatla, nerede, nasıl kullanıldığı halka bizzat gösterildi. Böylelikle halkın memnuniyeti sağlanırken, cemiyetin güvenilirliği arttırılarak emin adımlarla yola devam edilebildi. $\mathrm{Bu}$ doğrultuda bayramların en görkemli ve halkı

${ }^{60}$ Türk Hava Mecmuası, Sayı: 33, 1927, s.283.

${ }^{61}$ Günümüzde Çorum'a bağlıdır. 
onurlandıracak etkinliği kapsamında ilk sırada, halkın yaptığı yardımlarla alınan uçaklara- "ad verme töreni"'- isim verilmesi gelmekteydi. Yapılan yardımlar neticesinde, satın alma yolu ile temin edilen uçaklara, yardımı yapanların yahut yaşadıkları bölgenin isimleri verildi. Bu yolla, yardım yapanlar övüldü ve Türk Havacılığının belirli bir seviyeye gelmesi sağlandı. Cemiyetin, yakın hedef olarak belirlediği, ihtiyaç duyulan uçakların satın alınması, böylelikle bir süreliğine gerçekleştirilmiş oldu. Ancak, uzak hedef olarak belirlenen Türk Milletinin kendi tayyare fabrikasını kurma girişimleri başlangıçta kısıtlı seviyede gerçekleşmiş olsa da aynı Tayyare Bayramlarının bir süre sonra kutlanmayışı ve unutulması gibi istenen seviyeye ulaşamadi.

Erken Cumhuriyet Dönemi yöneticilerinin çok yoğun ve etkili bir şekilde faaliyet gösterdiği Türk Havacıllı̆̆nın gelişimi süreci maalesef ne cemiyetin ne de yöneticilerin istedikleri, arzuladıkları seviyede sürdürülememiş ve istenen seviyeye getirilememiştir. Bunda fikri sürekliliğin devam ettirilememesinin ve 1940 'lardan sonra havacilığa gereken önemin verilememesinin etkili olduğu görülmektedir.

\section{KAYNAKÇA}

\section{ARŞIV BELGELERI}

Cumhurbaşkanlığı Arşivi: Kutu No: 1/89 (23-1), Fihrist No: 61/4

Düstur, Cilt: 16, Üçüncü Tertip

Türk Tayyare Cemiyeti Beşinci Kongre Zabıtları 27-28 Teşrinisani 1932, Ankara: Hâkimiyeti Milliye Matbaası, 1932

Türk Tayyare Cemiyeti: Esas Nizamname ve Madalya Nizamnamesi, Ankara: Hâkimiyeti Milliye Matbaası, 1932

Türk Tayyare Cemiyeti, Nizamname-i Esasisi, Ankara Matbaas1, 1925.

\section{RESMI YAYINLAR}

TBMM Zabıt Ceridesi, Devre: 2, Cilt: 24.

\section{GAZETELER VE DERGILER}

Akşam, 30 Ağustos 1936.

Anadolu, 30 Ağustos 1934.

Ayın Tarihi, Say1: 18, 1-31 Mayıs 1935

Babalık, 28 Ağustos 1936

Babalık, 21 Ağustos 1936

Bingöl, 1937

Cumhuriyet, 31 Ağustos 1929

Gaziantep, 31 Ağustos 1931, s. 2; Hâkimiyeti Milliye, 1 Eylül 1931.

Kurun, 17 Nisan 1936.

Sabah, 26 Ağustos 1938, s. 1; Sabah, 27 Ağustos 1938.

Ulus, 31 Ağustos 1935. 
Ulus, 30 Ağustos 1937.

Tayyare Cemiyeti Mecmuas1, 10 Aralık 1925, Ankara, No:16-18.

Türk Hava Mecmuası, Say1 8, 15 Eylül 1926.

Türk Hava Mecmuası, Sayı 9, 1 Ekim 1926.

Türk Hava Mecmuası, Sayı: 33, 1927.

\section{KITAPLAR VE MAKALELER}

Evsile, Mehmet, Atatürk Devri Harp Sanayi (1920-1938), Hasan Celal Güzel vd. (Ed.), Türkler, Cilt: 17 Ankara: Yeni Türkiye.

Gökmen, Şakir Hazım, “Ulusal Hava Seferberliği”, Ulus, 1 Eylül 1935.

Göymen-Aslaner Güner, Doğu Anadolu'da Bulunan Ergani Maden Bakır Yatağının ve Bilhassa Yantaşlarının Maden Mikroskopik Incelenmesi, Maden Teknik Arama Enstitüsü, Ankara.

H.K.K., Tarihçe Şube Müdürlüğü, Gönüllerden Göklere, Ankara, 2005.

Hürkuş, Vecihi, Bir Tayyarecinin Anıları: Yaşantı, İstanbul, YKY, 2000.

Hürkuş, Vecihi, Havada, İstanbul, 2008.

Kaymakl1, Hulusi, Havacılık Tarihinde Türkler II, Kültür Ofset Ldt. Şti, Ankara, 1997.

Kocabaşoğlu, Uygur, Şirket Telsizinden Devlet Radyosuna, 1980.

Millet Büyük Larousse Sözlük ve Ansiklopedi, Birinci Cilt, 1986.

\section{WEB ADRESLERI}

www.ezgikonucu.com 